\title{
What Determines Foreign Direct Investment in Finances of OECD Countries
}

\author{
Yugang $\mathrm{HA}^{1}$, Baek-Ryul $\mathrm{CHOI}^{2}$
}

Received: September 19, 2019 Revised: October 16, 2019 Accepted: November 05, 2019

\begin{abstract}
Purpose: Global economic integration has provided good opportunities and conditions for the development of foreign direct investment in Finances. Therefore, this paper attempts to explore what determines foreign direct investment in Finances of Organization for Economic Co-operation and Development (OECD) countries. Research design, data and methodology: This paper employs the panel data over the period 2005-2017 and uses the random effect model to estimate this proposition. Results: The results indicate that the foreign direct investment in services, growth rate of GDP, interest rate and saving are positively related with foreign direct investment in finances. Conversely, the growth rate of wage and fluctuation rate of exchange rate are negatively related with foreign direct investment in finances. Moreover, the results verify that the effect of these variables on foreign direct investment in finances is different before and after 2008 (global economic crisis). In addition, the results also manifest that the regional effect exists. Namely, the effect of these variables on foreign direct investment in finances between G7 countries and G20 countries exist significant difference. Conclusions: Those variables used in this paper are related with foreign direct investment in Finances of (OECD) countries.
\end{abstract}

Keywords : Foreign Direct Investment in Finances, Global Economic Crisis, Regional Effect, Random Effect Model

JEL Classification Code : C33, F00, G00

\section{Introduction}

Analyzing the determinants of foreign direct investment is a very old economic proposition, which has been studied by a large number of scholars in related fields. Because of the different research objects and time spans, the research results of various scholars are different. Keeley and Ikeda (2017) try to explore the determinants of foreign direct investment in wind energy with a sample of developing countries. Their findings reveal that the effectiveness of renewable support policies, well-structured and credible

1 First author, Doctoral Student, Department of International Trade, Jeonbuk National University, Korea. Email: 1293647581@jbnu.ac.kr

2 Corresponding Author, Professor, Department of International Trade, Jeonbuk National University, Korea. Email: brchoi@jbnu.ac.kr

(c) Copyright: Korean Distribution Science Association (KODISA) This is an Open Access article distributed under the terms of the Creative Commons Attribution Non-Commercial License (http://creativecommons.org/licenses/by-nc/4.0/) which permits unrestricted noncommercial use, distribution, and reproduction in any medium, provided the original work is properly cited. regulatory support policies, economic support policies and Institutional aspects are important factors to attract the foreign direct investment in wind energy. Tokunaga and Iwasaki (2017) attempt to use a meta-analysis to analyze the determinants of foreign direct investment in transition. They find that the transition economy-specific factors have quantitatively exerted an influence on the foreign direct investment performance. Belgibayeva and Plekhanov (2019) use a cross-country empirical analysis to exploit the determinants of foreign direct investment. Their empirical findings reveal that the corruption is a strong significant factor that affect the foreign direct investment. However, in recent years, with the deepening global economic integration, the capital account liberalization has become a country's economy into the inevitable result of globalization. Making profits for each country through financial means has also become very popular. Therefore, this paper takes Organization for Economic Co-operation and Development (OECD) countries as a sample to explore what determines foreign direct investment in finances. Using the panel annual data over the period 2005 to 2017 and employing the 
random effect model and two-step model to perform empirical analyses, the empirical findings exhibit that the foreign direct investment in services, trade openness, growth rate of GDP, interest rate and rate of saving are the positive factors that attract the foreign direct investment in finances. On the contrary, the fluctuation rate of exchange rate and growth rate of wage level are the negative factors that block to attract the foreign direct investment in finances. Meanwhile, two sub-samples are formed due to global economic crisis in 2008. Both sub-samples are re-estimated under the random effect model. We find that a significant difference between before and after 2008 exists on attracting the foreign direct investment in finances. Moreover, a regional effect is also taken into account. Therefore, two sub-samples (G7 and G20) are re-estimated under the random effect model. We find that the regional effect on attracting the foreign direct investment in finances also exists. These empirical results this paper provided are consistent with the research hypotheses.

This paper contributes to the existing literature in two aspects. One is that most current papers have concentrated on the determinants of foreign direct investment in general concept. Bur this paper investigates the determinants of foreign direct investment in finances. This settlement is more specific than that of previous. The other is that most papers focuses on the demand or supply factors to discuss the attraction of foreign direct investment. In this paper, both the demand factors and supply factors are all taken into consideration. This settlement may produce different expectations and perspectives on the issue of attracting the foreign direct investment in finances. The focus is OECD countries, the most developed countries in the world, which need more to attract more foreign direct investment in finances to develop their countries.

The rest of this paper forms as follows: Section two provides the literature review and research hypotheses; Section three presents the research framework; Section four addresses multivarite analysis, findings and discussion. Section five shows the conclusion and suggestion.

\section{Literature Review and Research Hypotheses}

In recent years, how to carry out the foreign direct investment has become a hot economic topic. Experts in related fields have put forward different theories on this proposition. In fact, there are many factors affecting the behavior of foreign direct investment, which can be roughly divided into two categories. One is from the country who provides the foreign direct investment, the other is from the country who receives the foreign direct investment. This section mainly analyzes the previous researches, which can be regarded as the theoretical bases of this paper. Meanwhile, based on these analyses in this section, seven hypotheses will be put forward.

Klasra (2011) sets Pakistan and Turkey as an example and attempts to explore the relationship between foreign direct investment and trade openness using the bounds test. Applying the data from 1975 to 2004 to conduct empirical analyses, he finds that the trade openness has a positive effect on foreign direct investment, but only significant in statistic in Turkey. Liargovas and Skandalis (2012) employ a sample of 36 developing countries over the period 19902008 to testify the significance of trade openness on attracting the inflows of foreign direct investment. They directly test the causal relationship among inflows of foreign direct investment, trade openness and other key variables in the developing regions. Via the panel regression analyses, their main empirical results manifest that the trade openness is positively related with the inflows of foreign direct investment in developing countries in the long run. Kim, Lin and Suen (2013) apply the instrumental variable threshold regressions approach to investigate the impact of trade openness on foreign direct investment with a sample of cross-sectional data for 85 countries. They find that the trade openness adversely affects investment in low-human-capital, less-financially-developed, or more-corrupted countries, but positively affects it in countries with opposite attributes. Seyoum, Wu and Lin (2014) use the annual balanced panel data for 25 Sub-Saharan African countries over the period 1977-2009 to examine the Granger causality relationship between trade openness and foreign direct investment. They find that there is a bidirectional causal relationship between trade openness and foreign direct investment in Sub-Saharan countries. Namely, the trade openness is an important factor that attracts more foreign direct investment. Boateng, Hua, Nisar and Wu, (2015), Pradhan, Arvin, Hall and Nair (2017), Cantah, Brafu-Insaidoo, Wiafe and Adams (2018) also find the same results on the effect of trade openness on foreign direct investment even though with different samples and different time spans.

Pao and Tsai (2011) regard BRIC countries as a sample with panel data over the period 1980-2007 to exploit the Granger causality between economic growth and foreign direct investment. They find that there is an unidirectional strong causality which is running from economic growth to foreign direct investment. Cole, Elliott and Zhang (2011) agree that of Pao and Tsai (2011). However, Belloumi (2014) uses the data over the period 1970 to 2008 from Tunisia and employ the the autoregressive distributed lag model to address the relationship between economic growth and foreign direct investment. He finds that there is no significant Granger causality from economic growth to foreign direct investment. Omri, Nguyen and Rault (2014) apply the dynamic simultaneous-equation panel data models with a sample of 54 countries over the period 1990-2011 to examine the causality relationship between foreign direct investment and economic growth. Moreover, they also divide the full sample into three sub-samples. Their empirical findings indicate that the economic growth is always positively related to foreign direct investment. But only a small difference exists in significant levels in statistic. Kivyiro and Arminen (2014) use Sub-Saharan Africa to explain the relationship between economic growth and 
foreign direct investment. They also find that the economic growth is a strong factor that impact the behavior of foreign direct investment.

Figini and Görg (2011) utilize more than 100 countries over the period 1980-2002 to discuss the relationship between foreign direct investment and wage inequality. Va the nonlinear empirical analyses, they find that there is a negative relationship between foreign direct investment and wage inequality. Chen, Ge and Lai (2011) set China as an example to study the same proposition. Using the fixed effect model to conduct empirical analysis, they draw the same conclusion. Hale and Long (2011) also obtain the same result. Ullah, Haider and Azim (2012) take Pakistan as research object to analyze the exchange rate volatility on foreign direct investment. Using the time series over the period 1980-2010, they find that the exchange rate volatility has a negative and significant effect on foreign direct investment. Alam and Zulfiqar Ali Shah (2013) treat OECD as a sample to study the determinants of foreign direct investment. Employing the Granger causality tests to fulfil empirical analyses, they find that exchange rate is a negatively related to foreign direct investment. Ramasamy and Yeung (2010) use OECD countries as a sample over the period 1980-2003 to discuss the determinants of foreign direct investment in services. They find that the high interest rate will attract more foreign direct investment. This finding is consistent with the result of Kolstad and Villanger (2008). Gordon, Loeb and Zhu (2012) use a panel data set of over 1300 observations which are covering 124 countries over the period 1996-2009 to argue the same proposition. Via the empirical analyses under the two-stage instrumental variable model, their finding manifests that the interest rate is positively related with foreign direct investment.

Buckley and Casson (2010) investigate the relationship between domestic savings and foreign direct investment. They find that the domestic savings have a positive effect on foreign direct investment. Selaya and Sunesen (2012) agree with that of Buckley and Casson (2010). Ramasamy, Yeung and Laforet (2012) set China as an example to discuss China's outward foreign direct investment. They find that saving rate is positively related with foreign direct investment. Since the foreign direct investment in services will be provide convenience for the foreign direct investment in finances, the relationship between both of them will be positive. Moreover, based on literature analyses above, seven hypotheses are put forward as follows:

Hypothesis 1: Foreign direct investment in services has a positive effect on foreign direct investment in finances.

Hypothesis 2: Dependence on foreign trade has a positive effect on foreign direct investment in finances.

Hypothesis 3: Growth rate of GDP has a positive effect on foreign direct investment in finances.
Hypothesis 4: Fluctuation rate of exchange rate has a negative effect on foreign direct investment in finances.

Hypothesis 5: Growth rate of wage level has a negative effect on foreign direct investment in finances.

Hypothesis 6: Interest rate has a positive effect on foreign direct investment in finances.

Hypothesis 7: Rate of saving has a positive effect on foreign direct investment in finances.

\section{Research Framework}

\subsection{Variable Description}

In general, the factors that affect the behavior of foreign direct investment mainly come from two aspects which include the demand and supply. In terms of demand, the factors that affect the behavior of foreign direct investment contain the market potential and facilitation. In terms of supply, the factors that affect the behavior of foreign direct investment consists of rate of return and labor cost. The selection of explanatory variables in this paper is based on this principle. The explanatory variable includes the foreign direct investment in services, trade openness, growth rate of GDP, fluctuation rate of exchange rate, growth rate of wage level, interest rate and rate of saving. Due to that this paper discusses the determinants of foreign direct investment in finances, the foreign direct investment in finance will be treated as explained variable. All these variables over the period 2000-2018 are sourced from OECD Data Center.

\subsection{Model Specification}

Based on the analysis in Variable Description, the estimated model used in this paper gives as follows:

$$
\begin{aligned}
& \text { fdi }_{i, t}^{f i}=a_{0}+a_{1} \text { fdi }_{i, t}^{s}+a_{2} \text { open }_{i, t}+a_{3} \text { growth }_{i, t-1} \\
& +a_{4} \text { fluctuatio }_{i, t-1}+a_{5} \text { wage }_{i, t-1}+a_{6} \text { int } \text { erest }_{i, t-1} \\
& +a_{7} \text { saving }_{i, t-1}+\mu_{i}+v_{t}+\varepsilon_{i, t}
\end{aligned}
$$

Where $i$ indicates each country of OECD; $t$ indicates the year; $f d i i_{i, t}$ indicates the ratio of foreign direct investment amount in finances (foreign direct investment amount is absorbed via finances) to the total foreign direct investment amount. $f d i^{i}{ }_{i, t}$ indicates the ratio of foreign direct investment amount in services to the total foreign direct investment amount. It represents the scale of foreign direct investment in services; open $_{i, t}$ indicates the ratio of sum of export and import trade to GDP. It represents the export \& import scale; growth $_{i, t}$ indicates the growth rate of GDP. It represents the 
potential of market growth of each country; fluctuation $_{i, t}$ indicates the fluctuation rate of exchange rate. It represents the stability of foreign exchange market; wage $_{i, t}$ indicates growth rate of wage level. It represents the labor cost of each country; interest $t_{i, t}$ indicates the interest rate. It represents the rate of return. saving $_{i, t}$ indicate the ratio of saving to GDP. It represent the dependence on finance and insurance of each country; $a_{0}$ indicates the constant; $a_{1} \ldots a_{7}$ indicate coefficients of each variable, respectively; $\mu_{i}$ indicates the country fixed effect; $v_{t}$ indicates the year fixed effect. $\varepsilon_{i, t}$ indicates the white noise.

\section{Empirical Analysis}

\subsection{Basic Statistics}

Results of Basic statistics are presented in $\langle$ Table 1> in the Appendix. The mean value of foreign direct investment in finances is 0.258 with a standard deviation 0.158 . The mean value of foreign direct investment in services is 0.617 with a standard deviation 0.155 . The mean value of trade openness is 1.025 with a standard deviation 0.677 . The mean value of growth rate of GDP is 0.042 with a standard deviation 0.081 . The mean value of fluctuation rate of exchange rate is 0.028 with a standard deviation 0.081 . The mean value of growth rate of wage level is 0.014 with a standard deviation 0.031 . The mean value of interest rate is 0.027 with a standard deviation 0.020 . The mean value of rate of saving is 0.068 with a standard deviation 0.060 .

\subsection{Correlation Test}

Results of correct test are presented in $\langle$ Table 2> in the Appendix. Based on the regulations of Gujarati, if the coefficient of correlation between two variables exceeds 0.800 , a strong multicollinearity problem will be existed. As the results of <Table 2> indicates, the coefficient of correlation between dependence on foreign trade and foreign direct investment in services is 0.614 . And the coefficients of correction of rest variables range from 0.000 to 0.401 . This means that a relative strong multicollinearity problem exists between dependence on foreign trade and foreign direct investment in services. Therefore, a two-step approach will be used to remove the relative strong multicollinearity problem.

\subsection{Multivarite Analysis, Findings and Discussion}

Before analyzing the relationship among these variables used in this paper, a proper econometric technique should be applied. A pooled ordinary least squares (pooled OLS), random effect model and fixed effect model are employed to fulfil empirical analyses, respectively. Via the result of
Chow test, we find that the null hypothesis ( $H_{0}$ : pool OLS) is rejected due to that statistics of Chow test (18.645) is greater than 1.520 (5\% significant level). Via the result of Hausman test, we find that the null hypothesis $\left(H_{0}\right.$ : random effect model) is not rejected due to that statistics of Hausman test is 6.700 with the probability value 0.570 . Finally, the random effect model will be used to confirm the relationship among these variables. Because the behaviors of foreign direct investment in services and dependence on foreign trade happen simultaneously, both of them are treated as explanatory variables. Moreover, a result of the lag of the influence of control variables and the avoidance of endogenous problems, one lag period of growth rate of GDP, fluctuation rate of exchange rate, growth rate of wage level, interest rate and rate of saving will be treated as control variables. The empirical results are presented in $\langle$ Table 3>. The coefficient of foreign direct investment in services is positive, but only significant at $10 \%$ level in statistic. The coefficient of trade openness is positive and significant at $1 \%$ level in statistic. The coefficient of growth rate of GDP is positive and significant at $1 \%$ level in statistic. The coefficients of growth rate of wage level and fluctuation rate of exchange rate are negative and significant at $1 \%$ level in statistic. The coefficients of interest rate and rate of saving are positive and significant at $1 \%$ level in statistic. More importantly, the results are consistent with the hypotheses in Section two. Owing to the multicollinearity problem, some coefficients are not significant enough in statistic. In order to remove the multicollinearity problem, a two-step technique will be used. The first-step model gives:

$$
\text { open }_{i, t}=\beta_{0}+\beta_{1} f d i_{i, t}^{s}+\varpi_{i, t}
$$

Where $\beta_{0}$ indicates the constant; $\beta_{1}$ indicates the coefficient; $\varpi$ is the white noise which will be marked as $\operatorname{Re}(\varpi=\operatorname{Re})$. Re will be added to equation (1) to re-estimate the relationship among these variables. The re-estimated results are presented at $\langle$ Table 4$\rangle$. We find that the coefficient of foreign direct investment in services increases from 0.626 to 767 and significant at $1 \%$ level in statistic.

\subsubsection{Effect of Global Economic Crisis on Foreign Direct Investment in Finances}

As the global economic crisis swept over the world in 2008, especially in the financial related industries, we will conduct empirical analyses before and after the global economic crisis to explore the difference of foreign direct investment in finances being shocked by the global economic crisis. The empirical results are presented in $\langle$ Table 5> in the Appendix. We find that the coefficient of foreign direct investment in services increases from 0.606 to 0.765 and more significant in statistic after 2008. This means that the impact of foreign direct investment in services on foreign direct investment in finances is not influenced by the global economic crisis. The coefficient of growth rate of GDP increases from 0.123 to 0.126 , but only 
significant in statistic after 2008. This means that the impact of growth rate of GDP on foreign direct investment in finances is not influenced by the global economic crisis. The coefficient of growth rate of wage level decreases from -0.111 to -0.192 , but only significant in statistic after 2008 . This means that the effect of growth rate of wage level foreign direct investment in finances is greatly influenced by the global economic crisis. The coefficient of interest rate decreases from 0.798 to 0.687 and only significant at $1 \%$ level in statistic. This means that the impact of interest rate on foreign direct investment in finances is weakened due to the global economic crisis. The coefficient of rate of saving increases from 0.178 to 0.215 , but not significant in statistic. The coefficient of fluctuation rate of exchange rate increases from -0.100 to -0.072 and significant at $1 \%$ level in statistic. This means that the impact of fluctuation rate of exchange rate on foreign direct investment in finances is weakened due to the global economic crisis. These results prove that the effect of those variables used in this paper on foreign direct investment in finances is different before and after the global economic crisis.

\subsubsection{Effect of Religion (G7 and G20) on Foreign Direct Investment in Finances}

Because OECD countries include various international organizations which have different backgrounds and economic policies, this will lead to imbalances in regional development. In general, G7 countries are more developed than G20 countries in economy. Therefore, this paper employs G7 countries and part of G20 countries which belongs to OECD countries as two sub-samples to perform empirical analyses, respectively. The estimated results in $<$ Table 6> in the Appendix. We find that the coefficient of foreign direct investment in services increases from 0.490 to 0.593 and more significant in statistic at G20 countries. The coefficient of growth rate of GDP increases from 0.138 to 0.162 , but less significant in statistic at G20 countries. The coefficient of growth rate of wage level decreases from -0.162 to 0.191 and significant at $1 \%$ in statistic. The coefficient of interest rate increases from 0.626 to 0.842 and significant at $5 \%$ in statistic. The coefficient of rate of saving decreases from 0.160 to 0.142 and significant at $10 \%$ in statistic. The coefficient of fluctuation rate of exchange rate increases from -0.050 to -0.034 , but less significant in statistic at G20 countries. The differences of coefficients between G7 and G20 verify that the regional effect really exists.

\section{Conclusion}

Using OECD countries as a sampler over the period 2005-2017, this paper attempts to explore what determines foreign direct investment in finances. Based on the empirical analyses under the framework of the random effect model and two-step model, we find that the trade openness, growth rate of GDP, interest and rate of saving are positively related with the foreign direct investment in finances. Conversely, the fluctuation rate of exchange rate and growth rate of wage level are negatively related with the foreign direct investment in finances. Due to that a relative strong multicolinearity between trade open and foreign direct investment in services exists, a two-step model is employed to remove the problem of multicolinearity. We re-estimate the effect of these variables used in this paper on foreign direct investment in Finances. The empirical findings indicate that the effect of foreign direct investment in services increases from 0.626 to 0.767 and becomes more significant in statistic. Since the global economic crisis has a huge impact on economy in the world, especially in the industries related to finances, the empirical findings manifest that the effect of variables used in this paper on foreign direct investment in finances appears a great differences before and after 2008. Additionally, because the regional effect also affects the behavior of foreign direct investment in finances, two sub-samples (G7 and G20) are set to re-estimate the effect of variables used in this paper on foreign direct investment in finances. The empirical findings demonstrate that the regional effect on foreign direct investment in finances unquestionably exists.

Based on the empirical evidences this paper gives, some related corresponding measures are provided. Firsts, OECD countries should pay more attention to the foreign direct investment in services, the reason is that OECD countries with more foreign direct investment in services have the ability of attracting more foreign direct investment in finances. Second, a country should spare no effort to develop its economy. The reason is that the growth rate of GDP is still an important factor that attracts the foreign direct investment in finances. Third, OECD countries should establish a perfect exchange rate system, because a large fluctuation of exchange rate will reduce the foreign direct investment in finances. Fourth, OECD countries should establish a reasonable wage mechanism, because a rise in the growth rate of wage will reduce the foreign direct investment in finances. Fifth, OECD countries should form an interest rate system, because a high interest rate will attract more foreign direct investment in finances. Sixth, OECD countries should form a good system of bank deposit and loan, because a high rate of saving country will attract more foreign direct investment in finances. Finally, due to the lack of some data and the short annual span, the accuracy of empirical results will be affected to some extent.

\section{References}

Alam, A., \& Zulfiqar Ali Shah, S. (2013). Determinants of foreign direct investment in OECD member countries. Journal of Economic Studies, 40(4), 515-527.

Belgibayeva, A., \& Plekhanov, A. (2019). Does corruption matter for sources of foreign direct investment?. Review of World Economics, 155(3), 487-510. 
Belloumi, M. (2014). The relationship between trade, FDI and economic growth in Tunisia: An application of the autoregressive distributed lag model. Economic Systems, $38(2), 269-287$.

Boateng, A., Hua, X., Nisar, S., \& Wu, J. (2015). Examining the determinants of inward FDI: Evidence from Norway. Economic Modelling, 47, 118-127. https://doi.org/10.1016/j.econmod.2015.02.018.

Buckley, P. J., \& Casson, M. (2010). The optimal timing of a foreign direct investment. In The Multinational Enterprise Revisited (pp. 25-40). Palgrave Macmillan, London. https://doi.org/10.1057/9780230250468_2.

Cantah, G. W., Brafu-Insaidoo, G. W., Wiafe, E. A., \& Adams, A. (2018). FDI and Trade Policy Openness in Sub-Saharan Africa. Eastern Economic Journal, 44(1), 97-116.

Chen, Z., Ge, Y., \& Lai, H. (2011). Foreign direct investment and wage inequality: Evidence from China. World Development, 39(8), 1322-1332.

Cole, M. A., Elliott, R. J., \& Zhang, J. (2011). Growth, foreign direct investment, and the environment: Evidence from Chinese cities. Journal of Regional Science, 51(1), 121-138.

Figini, P., \& Görg, H. (2011). Does foreign direct investment affect wage inequality?: An empirical investigation. The World Economy, 34(9), 1455-1475.

Gordon, L. A., Loeb, M. P., \& Zhu, W. (2012). The impact of IFRS adoption on foreign direct investment. Journal of Accounting and Public Policy, 31(4), 374-398.

Hale, G., \& Long, C. (2011). Did foreign direct investment put an upward pressure on wages in China? IMF Economic Review, 59(3), 404-430.

Keeley, A. R., \& Ikeda, Y. (2017). Determinants of foreign direct investment in wind energy in developing countries. Journal of Cleaner Production, 161, 1451-1458. https://doi.org/10.1016/j.jclepro.2017.05.106.

Kim, D. H., Lin, S. C., \& Suen, Y. B. (2013). Investment, trade openness and foreign direct investment: Social capability matters. International Review of Economics \& Finance, $\quad 26, \quad 56-69$. https://doi.org/10.1016/j.iref.2012.08.008.

Kivyiro, P., \& Arminen, H. (2014). Carbon dioxide emissions, energy consumption, economic growth, and foreign direct investment: Causality analysis for SubSaharan. Africa. Energy, 74, 595-606. https://doi.org/10.1016/j.energy.2014.07.025.
Klasra, M. A. (2011). Foreign direct investment, trade openness and economic growth in Pakistan and Turkey: An investigation using bounds test. Quality \& Quantity, 45(1), 223-231.

Kolstad, I., \& Villanger, E. (2008). Determinants of foreign direct investment in services. European Journal of Political Economy, 24(2), 518-533.

Liargovas, P. G., \& Skandalis, K. S. (2012). Foreign direct investment and trade openness: The case of developing economies. Social Indicators Research, 106(2), 323-331.

Omri, A., Nguyen, D. K., \& Rault, C. (2014). Causal interactions between $\mathrm{CO} 2$ emissions, FDI, and economic growth: Evidence from dynamic simultaneous-equation models. Economic Modelling, 42, 382-389. https://doi.org/10.1016/j.econmod.2014.07.026.

Pao, H. T., \& Tsai, C. M. (2011). Multivariate Granger causality between $\mathrm{CO} 2$ emissions, energy consumption, FDI (foreign direct investment) and GDP (gross domestic product): Evidence from a panel of BRIC (Brazil, Russian Federation, India, and China) countries. Energy, 36(1), 685-693.

Pradhan, R. P., Arvin, M. B., Hall, J. H., \& Nair, M. (2017). Trade openness, foreign direct investment, and financegrowth nexus in the Eurozone countries. The Journal of International Trade \& Economic Development, 26(3), 336-360.

Ramasamy, B., \& Yeung, M. (2010). The determinants of foreign direct investment in services. World Economy, 33(4), 573-596.

Ramasamy, B., Yeung, M., \& Laforet, S. (2012). China's outward foreign direct investment: Location choice and firm ownership. Journal of World Business, 47(1), 17-25.

Selaya, P., \& Sunesen, E. R. (2012). Does foreign aid increase foreign direct investment?. World Development, 40(11), 2155-2176.

Seyoum, M., Wu, R., \& Lin, J. (2014). Foreign direct investment and trade openness in Sub- Saharan economies: A panel data granger causality analysis. South African Journal of Economics, 82(3), 402-421.

Tokunaga, M., \& Iwasaki, I. (2017). The determinants of foreign direct investment in transition economies: A Meta-analysis. The World Economy, 40(12), 2771-2831.

Ullah, S., Haider, S. Z., \& Azim, P. (2012). Impact of exchange rate volatility on foreign direct investment: A case study of Pakistan. Pakistan Economic and Social Review, 50(2), 121-138. 


\section{Appendix}

Table 1: Results of Basic Statistics

\begin{tabular}{|c|c|c|c|c|c|c|c|c|}
\hline $\begin{array}{c}\text { Statistic } \\
\text { Variable }\end{array}$ & $\boldsymbol{f d i}^{\boldsymbol{f i}}$ & $\boldsymbol{f d i}^{\boldsymbol{s}}$ & open & growth & fluctuation & wage & interest & saving \\
\hline Mean & 0.258 & 0.617 & 1.025 & 0.042 & 0.028 & 0.014 & 0.027 & 0.068 \\
\hline Median & 0.252 & 0.615 & 0.844 & 0.042 & 0.001 & 0.009 & 0.023 & 0.058 \\
\hline Maximum & 0.973 & 0.999 & 4.164 & 0.142 & 0.229 & 0.234 & 0.124 & 0.246 \\
\hline Minimum & 0.051 & 0.310 & 0.271 & -0.150 & -0.150 & -0.097 & -0.004 & -0.049 \\
\hline Std. Dev. & 0.158 & 0.155 & 0.677 & 0.081 & 0.081 & 0.031 & 0.020 & 0.060 \\
\hline
\end{tabular}

Table 2: Results of Correlation Test

\begin{tabular}{|c|c|c|c|c|c|c|c|c|}
\hline Variable & $f d i^{f i}$ & $f d i^{s}$ & open & growth & fluctuation & wage & interest & saving \\
\hline$f d i^{f i}$ & $\begin{array}{c}1.000 \\
--- \\
-- \\
\{4472\} \\
\end{array}$ & & & & & & & \\
\hline$f d i^{s}$ & $\begin{array}{c}0.116^{\star \star \star} \\
(10.132) \\
{[0.000]} \\
\{4472\}\end{array}$ & $\begin{array}{c}1.000 \\
--- \\
--- \\
\{4472\}\end{array}$ & & & & & & \\
\hline open & $\begin{array}{c}0.149^{* * *} \\
(11.048) \\
{[0.000]} \\
\{4472\}\end{array}$ & $\begin{array}{c}0.614^{* * *} \\
(7.770) \\
{[0.000]} \\
\{4472\}\end{array}$ & $\begin{array}{c}1.000 \\
--- \\
--- \\
\{4472\}\end{array}$ & & & & & \\
\hline growth & $\begin{array}{c}0.084 \\
(1.094) \\
{[0.276]} \\
\{4472\}\end{array}$ & $\begin{array}{c}0.038 \\
(0.498) \\
{[0.619]} \\
\{4472\}\end{array}$ & $\begin{array}{l}0.074 \\
(0.958) \\
{[0.340]} \\
\{4472\}\end{array}$ & $\begin{array}{c}1.000 \\
--- \\
--- \\
\{4472\}\end{array}$ & & & & \\
\hline fluctuatio $n$ & $\begin{array}{c}0.000 \\
(0.005) \\
{[0.996]} \\
\{4472\}\end{array}$ & $\begin{array}{c}-0.019 \\
(-0.244) \\
{[0.808]} \\
\{4472\}\end{array}$ & $\begin{array}{l}0.046 \\
(0.591) \\
{[0.556]} \\
\{4472\}\end{array}$ & $\begin{array}{c}-0.392^{\star \star \star} \\
(-5.521) \\
{[0.000]} \\
\{4472\}\end{array}$ & $\begin{array}{c}1.000 \\
---- \\
--- \\
\{4472\}\end{array}$ & & & \\
\hline wage & $\begin{array}{c}0.057 \\
(0.739) \\
{[0.461]} \\
\{4472\} \\
\end{array}$ & $\begin{array}{c}0.040 \\
(0.514) \\
{[0.608]} \\
\{4472\} \\
\end{array}$ & $\begin{array}{c}0.087 \\
(1.136) \\
{[0.258]} \\
\{4472\}\end{array}$ & $\begin{array}{c}0.401^{\star * *} \\
(5.678) \\
{[0.000]} \\
\{4472\}\end{array}$ & $\begin{array}{c}-0.067 \\
(-0.864) \\
{[0.389]} \\
\{4472\}\end{array}$ & $\begin{array}{c}1.000 \\
---- \\
--- \\
\{4472\} \\
\end{array}$ & & \\
\hline int erest & $\begin{array}{c}-0.179^{* *} \\
(-2.360) \\
{[0.019]} \\
\{4472\}\end{array}$ & $\begin{array}{l}-0.194^{\star *} \\
(-2.564) \\
{[0.011]} \\
\{4472\}\end{array}$ & $\begin{array}{c}-0.177^{* *} \\
(-2.332) \\
{[0.021]} \\
\{4472\}\end{array}$ & $\begin{array}{c}-0.035 \\
(-0.455) \\
{[0.649]} \\
\{4472\}\end{array}$ & $\begin{array}{c}-0.199^{\star * *} \\
(-2.627) \\
{[0.009]} \\
\{4472\}\end{array}$ & $\begin{array}{c}-0.108 \\
(-1.408) \\
{[0.161]} \\
\{4472\}\end{array}$ & $\begin{array}{c}1.000 \\
---- \\
--- \\
\{4472\} \\
\end{array}$ & \\
\hline saving & $\begin{array}{c}0.012 \\
(0.159) \\
{[0.874]} \\
\{4472\}\end{array}$ & $\begin{array}{c}-0.233^{\star \star \star} \\
(-3.102) \\
{[0.002]} \\
\{4472\}\end{array}$ & $\begin{array}{c}-0.010 \\
(-0.128) \\
{[0.898]} \\
\{4472\}\end{array}$ & $\begin{array}{c}0.017 \\
(0.223) \\
{[0.824]} \\
\{4472\}\end{array}$ & $\begin{array}{c}0.009 \\
(0.117) \\
{[0.907]} \\
\{4472\}\end{array}$ & $\begin{array}{c}-0.063 \\
(-0.822) \\
{[0.412]} \\
\{4472\}\end{array}$ & $\begin{array}{c}-0.058 \\
(-0.749) \\
{[0.455]} \\
\{4472\}\end{array}$ & $\begin{array}{c}1.000 \\
--- \\
-- \\
\{4472\}\end{array}$ \\
\hline
\end{tabular}


Table 3: Results of Pooled OLS, Random Effect, Individual Fixed Effect

\begin{tabular}{|c|c|c|c|}
\hline Explained variable & \multicolumn{3}{|c|}{$f d i^{f i}$} \\
\hline Explanatory variable & Pooled OLS & Random Effect & Individual Fixed Effect \\
\hline$f d i_{t}^{s}$ & $\begin{array}{c}0.424 \\
(0.374)\end{array}$ & $\begin{array}{l}0.626^{*} \\
(0.329)\end{array}$ & $\begin{array}{c}0.671 \\
(0.453)\end{array}$ \\
\hline open $_{t}$ & $\begin{array}{l}0.102^{* * *} \\
(0.024)\end{array}$ & $\begin{array}{c}0.064^{\star \star * \star} \\
(0.015)\end{array}$ & $\begin{array}{c}0.027 \\
(0.018)\end{array}$ \\
\hline growth $_{\mathrm{t}-1}$ & $\begin{array}{c}0.170 \\
(0.163)\end{array}$ & $\begin{array}{c}0.152^{* * *} \\
(0.054)\end{array}$ & $\begin{array}{l}0.116^{*} \\
(0.068)\end{array}$ \\
\hline fluctuatio $n_{t-1}$ & $\begin{array}{l}-0.004 \\
(0.120)\end{array}$ & $\begin{array}{c}-0.070^{\star \star *} \\
(0.011)\end{array}$ & $\begin{array}{l}-0.083 \\
(0.059)\end{array}$ \\
\hline wage $_{t-1}$ & $\begin{array}{l}-0.0 .32 \\
(0.243)\end{array}$ & $\begin{array}{c}-0.143^{\star \star \star} \\
(0.041)\end{array}$ & $\begin{array}{l}-0.105^{\star *} \\
(0.048)\end{array}$ \\
\hline int erest $_{t-1}$ & $\begin{array}{l}-0.121 \\
(0.516)\end{array}$ & $\begin{array}{l}0.758^{*} \\
(0.407)\end{array}$ & $\begin{array}{l}0.708 \\
(0.538)\end{array}$ \\
\hline $\operatorname{saving}_{t-1}$ & $\begin{array}{c}0.296^{\star \star *} \\
(0.113)\end{array}$ & $\begin{array}{l}0.199^{*} \\
(0.119)\end{array}$ & $\begin{array}{c}0.181 \\
(0.139)\end{array}$ \\
\hline C & $\begin{array}{l}-0.132^{\star *} \\
(0.054)\end{array}$ & $\begin{array}{l}-0.228^{*} \\
(0.139)\end{array}$ & $\begin{array}{l}-0.168 \\
(0.225)\end{array}$ \\
\hline R-squared & 0.543 & 0.499 & 0.298 \\
\hline Chow-test & $18.645>1.520$ & & \\
\hline Hausman test & & $\begin{array}{c}6.700 \\
(p-\text { value }=0.570)\end{array}$ & \\
\hline Country-fixed effect & & No & Yes \\
\hline Year-fixed effect & & No & No \\
\hline Observations & 4472 & 4472 & 4472 \\
\hline
\end{tabular}

Table 4: Results of Two-step Regression

\begin{tabular}{|c|c|c|}
\hline Explained variable & \multicolumn{2}{|c|}{$f d i^{f i}$} \\
\hline Explanatory variable & One-step Regression & Two-step Regression \\
\hline$f d i_{t}^{s}$ & $\begin{array}{l}0.626^{*} \\
(0.329)\end{array}$ & $\begin{array}{c}0.767^{* \star *} \\
(0.220)\end{array}$ \\
\hline open $_{t}$ & $\begin{array}{c}0.064^{* * *} \\
(0.015) \\
\end{array}$ & \\
\hline growth $_{t-1}$ & $\begin{array}{c}0.152^{* \star *} \\
(0.054)\end{array}$ & $\begin{array}{c}0.152^{* * *} \\
(0.054)\end{array}$ \\
\hline fluctuatio $n_{t-1}$ & $\begin{array}{c}-0.070^{* \star \star} \\
(0.011)\end{array}$ & $\begin{array}{c}-0.070^{* \star *} \\
(0.011)\end{array}$ \\
\hline wage $_{t-1}$ & $\begin{array}{c}-0.143^{\star * *} \\
(0.041)\end{array}$ & $\begin{array}{c}-0.143^{\star \star *} \\
(0.041)\end{array}$ \\
\hline int erest $_{t-1}$ & $\begin{array}{l}0.758^{\star} \\
(0.407)\end{array}$ & $\begin{array}{l}0.758^{*} \\
(0.407)\end{array}$ \\
\hline $\operatorname{saving}_{t-1}$ & $\begin{array}{l}0.199^{*} \\
(0.119)\end{array}$ & $\begin{array}{l}0.199^{*} \\
(0.119)\end{array}$ \\
\hline $\mathrm{Re}_{t}$ & & $\begin{array}{l}0.064^{*} \\
(0.035) \\
\end{array}$ \\
\hline C & $\begin{array}{l}-0.228^{*} \\
(0.139)\end{array}$ & $\begin{array}{l}-0.250^{\star} \\
(0.142)\end{array}$ \\
\hline R-squared & 0.499 & 0.499 \\
\hline Country-fixed effect & No & No \\
\hline Year-fixed effect & No & No \\
\hline Observations & 4214 & 4214 \\
\hline
\end{tabular}


Table 5: Effect of Global Economic Crisis on Foreign Direct Investment in Finances

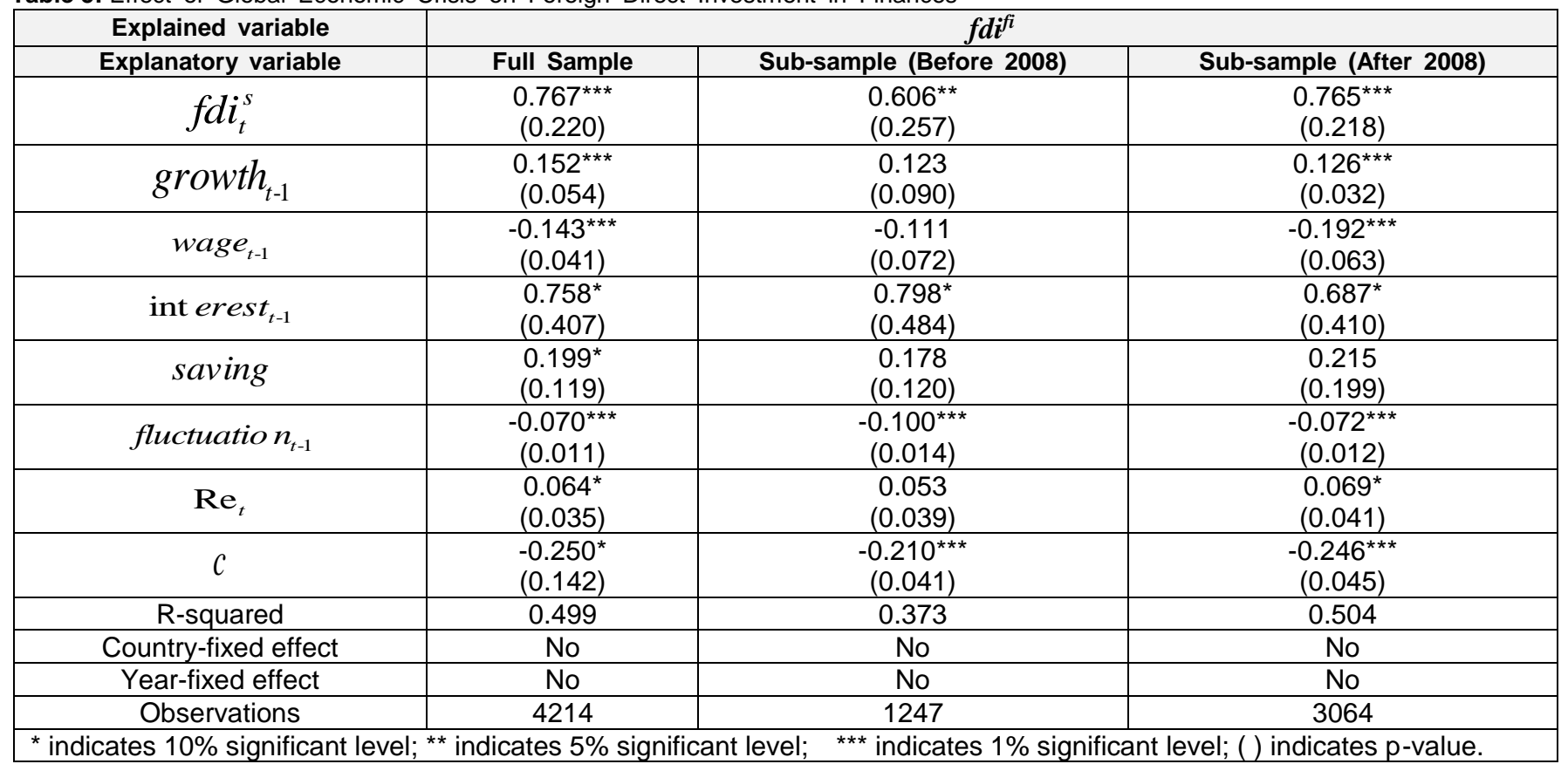

Table 6: Effect of Religion on Foreign Direct Investment in Finances

\begin{tabular}{|c|c|c|c|}
\hline \multirow{2}{*}{$\begin{array}{l}\text { Explained variable } \\
\text { Explanatory variable }\end{array}$} & \multicolumn{3}{|c|}{$f d i^{f i}$} \\
\hline & Full Sample & Sub-sample (G7 within OECD ) & Sub-sample (G20 within OECD) \\
\hline$f d i_{t}^{s}$ & $\begin{array}{c}0.767^{* \star *} \\
(0.220)\end{array}$ & $\begin{array}{l}0.490^{*} \\
(0.298)\end{array}$ & $\begin{array}{l}0.593^{* *} \\
(0.247)\end{array}$ \\
\hline growth $_{t-1}$ & $\begin{array}{l}0.152^{* * *} \\
(0.054)\end{array}$ & $\begin{array}{l}0.138^{* *} \\
(0.063)\end{array}$ & $\begin{array}{l}0.162^{*} \\
(0.084)\end{array}$ \\
\hline wage $_{t-1}$ & $\begin{array}{c}-0.143^{* \star \star} \\
(0.041)\end{array}$ & $\begin{array}{c}-0.162^{* \star *} \\
(0.043)\end{array}$ & $\begin{array}{c}-0.191^{* * *} \\
(0.049)\end{array}$ \\
\hline int $e^{2} e s t_{t-1}$ & $\begin{array}{l}0.758^{\star} \\
(0.407)\end{array}$ & $\begin{array}{l}0.626^{\star *} \\
(0.318)\end{array}$ & $\begin{array}{l}0.842^{\star *} \\
(0.375)\end{array}$ \\
\hline saving & $\begin{array}{l}0.199^{*} \\
(0.119)\end{array}$ & $\begin{array}{l}0.160^{*} \\
(0.089)\end{array}$ & $\begin{array}{l}0.142^{*} \\
(0.079)\end{array}$ \\
\hline fluctuatio $n_{t-1}$ & $\begin{array}{c}-0.070^{\star * \star} \\
(0.011)\end{array}$ & $\begin{array}{c}-0.050^{\star \star \star} \\
(0.015)\end{array}$ & $\begin{array}{l}-0.034^{*} \\
(0.019)\end{array}$ \\
\hline $\mathrm{Re}_{t}$ & $\begin{array}{l}0.064^{*} \\
(0.035)\end{array}$ & $\begin{array}{l}0.058^{\star *} \\
(0.023)\end{array}$ & $\begin{array}{l}-0.053^{\star *} \\
(0.024)\end{array}$ \\
\hline c & $\begin{array}{l}-0.250^{*} \\
(0.142)\end{array}$ & $\begin{array}{c}0.188 \\
(0.175)\end{array}$ & $\begin{array}{l}0.294^{* *} \\
(0.115)\end{array}$ \\
\hline R-squared & 0.499 & 0.201 & 0.638 \\
\hline Country-fixed effect & No & No & No \\
\hline Year-fixed effect & No & No & No \\
\hline Observations & 4472 & 864 & 1207 \\
\hline
\end{tabular}

